\title{
ЛОКАТИВНА ФУНКЦІЯ ЗНАХІДНОГО ВІДМІНКА В УКРАЇНСЬКІЙ І РОСІЙСЬКІЙ МОВАХ: ФАКТИ АСИМЕТРІЇ
}

Стаття має за мету виявити феномени міжмовної асиметрії - встановити факти невідповідності між українськими й російськими акузативними синтаксемами на рівні семантики, формально-граматичної організації, функціональних особливостей та стилістичної спеціалізаціі. 3'ясовано загальні риси симетріі на рівні реалізованих конкретними репрезентантами структурної моделі V+Prер+Nacс диференційованих значень (ідеться про синтаксичні конструкиї з прийменниками В/У [рос. В], НА, ЧЕРЕЗ, КРІЗЬ [рос. СКВОЗЬ], ЗА, ПІД [рос. ПОД]). Основну увагу приділено характеристиці семантичної, формально-граматичної, стилістичної асиметрії укра-

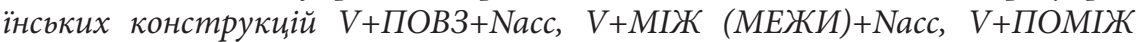
(ПОМЕЖИ)+Nacc, V+ПЕРЕД+Nacc, V+ПОПЕРЕД+Nacc, V+HAД+Nacc, V+ПОНАД+Nacc. Установлено маркери їхньої семантичності (прийменники, детермінувальні дієслова, детерміновані іменники), функиіональний потенціал, стилістичну ієрархію, за потреби - зв'язок з іншими неакузативними експлікаторами того або того просторового значення.

Ключові слова: споріднені украйнська й російська мови, локативні конструкиії, локативні прийменники, асиметрія, диференційоване просторове значення.

Stepanenko N. Locative Function of the Initial Pronoun in the Ukrainian and Russian Languages: Facts of Asymmetry. In linguistic science, exceptional relevance holds a comparative description of constructs with locative determination, which are the means of a profound understanding of the semantic macrofield of space. Priority task of modern linguistics includes the problem of comparative study of closely related languages.

The proposed article is devoted to the analysis of the locative nature of the initial pronoun in modern Ukrainian and Russian languages. The paper takes the view that deterministic and determinated constituents are involved in the formation of any meaning that is included in the semantic structure of "space". A peculiar identifiable behavior in constructions with a dependent prepositional form (and accusative also) has a preposition. It does not belong to a formal-organizational role, but a semanticgrammatical one.

The study found common features of symmetry at the level implemented by specific representatives of the structural model $V+$ Prep + Nacc. The main attention is paid to the characteristic of symmetric, formal-grammatical, stylistic asymmetry. It is about Ukrainian structures $V+P O V Z+N a c c, V+M I Z H ~(M E Z H Y)+N a c c$, 
$V+P O M I Z H(P O M E Z H Y)+N a c c, V+P E R E D+N a c c, V+P O P E R E D+N a c c$, $V+N A D+N a c c, V+P O N A D+N a c c$, for each of which is assigned a differentiated locative values, stylistic specification. Markers of their semantics (prepositions, determinative verbs, determinative nouns), functional potential, stylistic hierarchy are established, and, if necessary, - connection with other non-accusative explicators of one or another spatial meaning. An attempt was made to find the closest correspondences in the Russian language of Ukrainian constructions with the preposition POVZ + Nacc (Russian. MIMO + Ngen), MIZH (MEZHY) + Nacc, POMIZH (POMEZHY) + Nacc (Russian K + Ndat; MEZHDU + Ngen; MEZHDU+Ninst), PERED + Nacc, POPERED + Nacc (Ros. K + Ndat; PERED + Ninst), NAD + Nacc, PONAD + Nacc (Russian $K+$ Ndat; NAD + Ninst).

Key words: related Ukrainian and Russian languages, locative constructions, locative prepositions, asymmetry, differentiated spatial value.

\section{Вступ}

Дослідження багатомірної природи відмінкової парадигми залишається актуальним завданням сучасної науки про мову. «Розуміння відмінкової форми як неоднорідної сукупності семантико- й формально-синтаксичних функцій, - наголошує I. Р. Вихованець, - дозволило згрупувати граматичні явища на іншій - функціональній - основі й убачати в поліфункціональній відмінковій формі наявність і категоріального відмінкового значення, що розташоване на семантико-граматичній осі предметності й членується в ній на ряд різновидів, і категоріальних невідмінкових значень, категоріальність яких перебуває поза власне-відмінками й належить до несубстантивних частин мови» (Вихованець, 1987: 3). Важливо враховувати те, що «поліфункціональна відмінкова форма в семантико-синтаксичному плані може розчленовуватися на ряд значеннєвих компонентів, які не об'єднуються інваріантним значенням», отже, важливо в процесі аналізу охоплювати «всі різнорідні... значення» (там само) того або того відмінка, зрозуміло, і всі засоби його мовної інвентаризації.

Проблема знахідного відмінка здавна привертала увагу лінгвістів. Варто вирізнити праці Д. С. Станішевої про знахідний відмінок у східнослов'янських мовах (Станішева, 1966) та Є. К. Тимченка про синтаксис українського знахідного відмінка (Тимченко, 1928). Виняткове значення має монографія I. Р. Вихованця «Синтаксис знахідного відмінка в сучасній українській літературній мові», у якій грунтовно з’ясовано синтаксичні функції знахідного відмінка 
безприйменникового й прийменникового, установлено системні зв'язки його з іншими компонентами відмінкової парадигми (Вихованець, 1971). Логічним продовженням цієї студії стала монографія «Система відмінків української мови» (Вихованець, 1987). У ній різнобічно висвітлено синтаксичну специфіку акузатива, його первинні й вторинні семантико- й формально-синтаксичні функції, здатність до семантичного синкретизму, семантико-синтаксичну співвідносність знахідного й родового об’єктних, двох форм знахідного відмінка, розгортання синтаксичної специфікації називного й знахідного. Часткові аспекти порушеної проблеми висвітлені в працях Ю. І. Бєляєва, К. Г. Городенської, М. В. Мірченка, М. Я. Плющ та ін.

У пропонованій статті різновекторно схарактеризовано локативну специфікацію знахідного відмінка в компаративному - українсько-російському - вимірі. Основною метою ії $є$ виявлення феноменів міжмовної асиметрії, тобто встановлення фактів невідповідності між українськими та російськими акузативними синтаксемами на рівні семантики, формально-граматичної організації, функціональних особливостей та стилістичної спеціалізації.

\section{Методи та методики дослідження}

У дослідженні реалізувалися різні прийоми синхронного, порівняльно-історичного, зіставного методів, які поєднувалися з елементами статистичного методу. Як основний у роботі використано метод компонентного аналізу семантико-синтаксичних конструкцій, об’єднаних структурною моделлю V + Prep + Nacc.

\section{Результати та дискусіі}

За своєю семантико-синтаксичною природою знахідний відмінок $€$ багатозначним. Він активно реалізує об'єктні й обставинні семантико-синтаксичні відношення. До ядра адвербіальності акузатива належать локативні відношення. Конкретними репрезентантами валентної схеми $\mathrm{V}+$ знахідний локативний у російській та українській мовах є структурні моделі V + Nacc i V + Prep + Nacc. Конструкції $\mathrm{V}+\mathrm{Nacc}$ формуються на базі лексично обмеженої групи префіксальних дієслів, належать до розряду маловживаних і передають синкретичні просторово-об’єктні відношення. Центральність зберігається за семою «простір». Загальна семантика синтаксичних структур 
$\mathrm{V}+$ Prep + Nacc полягає у вказівці на рух чи іншу спрямовану дію. На виділене інваріантне значення нашаровуються семантичні відтінки, що уточнюють за різними параметрами локативну спрямованість. Вони формуються прийменником та іменником: B/У [рос. B] + Nacc «напрямок руху або іншої дії в межі чи всередину просторової одиниці»; НА + Nacc - «напрямок дії на поверхню предмета або в межі просторової одиниці»; ЧЕРЕЗ, КРІЗЬ [рос. ЧЕРЕЗ, СКВОЗЬ] + Nacc «напрямок наскрізного руху чи дії в межах просторової одиниці без подолання або з подоланням перешкод»; 3А + Nacc - «напрямок руху чи дії за межі просторової одиниці або на інший ії бік»; ПІД [рос. ПОД] + Nacc - «напрямок руху під просторову одиницю чи в нижню їі частину». Слід наголосити, що прийменники В і У в сучасній російській мові керують різними відмінками (В - знахідним і місцевим, У - родовим) і разом із субстантивами, що сполучаються з ними, реалізують неоднакову семантику. У сучасній українській мові ці два прийменники функціонально ідентичні, що є наслідком фонетичного злиття двох давніх прийменників - ВЪ та У. Їхнє вживання зумовлене не синтаксичними причинами, а фонетичними законами.

В українській мові в семантичній структурі моделі V + Prep + Nacc фіксуємо такі значення, які не функціонують у російській мові: ПОВ3 + Nacc - «напрямок дії мимо точки простору, але поблизу неї»; МІЖ (МЕЖИ) + Nacс ПОМІЖ (ПОМЕЖИ) + Nасс - «напрямок дії в межі простору, оточеного кількома орієнтирами»; НАД + Nacc, ПОНАД + Nacc - «напрямок дії в простір, що розташовується вище від предмета-орієнтира»; ПЕРЕД + Nacc, ПОПЕРЕД + Nacc - «напрямок дії до переднього боку об'єкта-орієнтира».

Конструкції з прийменниками ПОВЗ, МІЖ (МЕЖИ), ПОМІЖ (ПОМЕЖИ), НАД, ПОНАД належать до розряду маловживаних, що засвідчують результати суцільної вибірки, здійсненої на матеріалі текстів загальним обсягом 800 тисяч знаків у кожній із порівнюваних мов:

\begin{tabular}{|l|l|l|}
\hline $\begin{array}{c}\text { Конкретні репрезентанти моделі } \\
\text { V + Prep + Nacc }\end{array}$ & $\begin{array}{c}\text { Їхня кількість } \\
\text { (у \%) }\end{array}$ & \multicolumn{1}{|c|}{ Мови } \\
\hline $\mathrm{V}+\mathrm{B} / \mathrm{V}+\mathrm{Nacc}$ & $44,8 \%$ & українська \\
\hline $\mathrm{V}+\mathrm{B}+\mathrm{Nacc}$ & $48,6 \%$ & російська \\
\hline \multirow{2}{*}{$\mathrm{V}+\mathrm{HA}+\mathrm{Nacc}$} & $42,4 \%$ & українська \\
\cline { 2 - 3 } & $39,3 \%$ & російська \\
\hline
\end{tabular}




\begin{tabular}{|c|c|c|}
\hline \multirow{2}{*}{$\mathrm{V}+$ ЧEPE3 + Nacc } & $4,6 \%$ & українська \\
\hline & $5 \%$ & російська \\
\hline $\mathrm{V}+\mathrm{KPI} \mathrm{B}+\mathrm{Nacc}$ & $1,3 \%$ & українська \\
\hline $\mathrm{V}+\mathrm{CKBO} \mathrm{B}+\mathrm{Nacc}$ & $1 \%$ & російська \\
\hline \multirow{2}{*}{$\mathrm{V}+3 \mathrm{~A}+\mathrm{Nacc}$} & $2,6 \%$ & українська \\
\hline & $2,9 \%$ & російська \\
\hline $\mathrm{V}+$ ПІД + Nacc & $2,6 \%$ & українська \\
\hline $\mathrm{V}+$ ПОД + Nacc & $3,1 \%$ & російська \\
\hline $\mathrm{V}+\Pi \mathrm{OB} 3+\mathrm{Nacc}$ & $0,5 \%$ & українська \\
\hline V + МІЖ (МЕЖИ) + Nacc & $0,3 \%$ & українська \\
\hline V + ПОМІЖ (ПОМЕЖИ) + Nacc & $0,07 \%$ & українська \\
\hline V+ПЕРЕД+Nacc & $0,3 \%$ & українська \\
\hline V+ПОПЕРЕД+Nacc & $0,2 \%$ & українська \\
\hline V+HАД+Nacc & $0,26 \%$ & українська \\
\hline V+ПОНАД+Nacc & $0,07 \%$ & українська \\
\hline
\end{tabular}

Конструкція V + ПОВ3 + Nacc близька щодо семантики до синтаксичної структури V + MИМО + Ngen, яка функціонує в обох порівнюваних мовах. Проте, крім указівки на рух стосовно точки простору, синтаксеми з прийменником ПОВЗ містять додатковий відтінок «близькість ліній руху до об’єкта-орієнтира». Як і V + МИМО + Ngen, $\mathrm{V}+$ ПОВ3 + Nacс формується на базі дієслів динаміки та конкретної фізичної дії (рухатися, іти, плисти, понести, посунути, вертати, поїхати, проходити, тетіти, шмигнути, дивитися, кинути, гнати, пригортати, полоснути). Коло залежних компонентів широке. Його утворюють власні й загальні іменники. Особливою продуктивністю вирізняються лексеми - найменування осіб за різними ознаками (хлопець, дядько, господиня, українець, полтавець, учитель, лектор, Михайло, Кушнір). Уживаними є також назви споруд та їхніх частин (будинок, хата, кухня, поріг), чітко або недостатньо чітко лімітованих територій та акваторій (двір, поле, озеро, місто, вокзал, зупинка, пристань, Карпати, річка, острів): Знічений ... бочком пройшов повз господиню (А. Мороз), Омелян шмигнув повз Михайла (О. Десняк), Ця сама колона рухається й тепер повз вікна (І. Багряний), Вони мовчки проходять повз хату Василя Підіпригори (М. Стельмах), 3 молоддю поӥдуть повз двір Загнійного (Ю. Мушкетик), Темно-синя водяна стіна понеслася повз острів Хортицю в темні плавні (Я. Баш). Крім 
прийменника ПОВЗ, аналізована семантика реалізується за допомогою прийменників ПРОЗ і ПОПРОЗ, які є його «стильовими синонімами» (Іваненко, 1981: 86). 3 конструкцією ПОВ3 + Naсc семантично корелює синтаксична структура ПОПРИ + Nacc, що є iї «діалектним еквівалентом» (там само). Фактичний матеріал, який маємо в розпорядженні, дає підстави погодитися з думкою 3. І. Іваненко про те, що «стильові синоніми» фіксуються записами народного мовлення й творами художньої літератури, а «діалектний еквівалент» - записами народного мовлення й творами письменників західних областей України (там само): Катерина аж зраділа, побачивщи, що хтось швидко промайнув проз вікно і заходить у двір (О. Копиленко), Попроз мій городок стежечкою до іншої йдеш (П. Чубинський), - Якось iдy попри сад (В. Бабляк), Танки попри хату посунули на ріку (С. Пушик), ... тоді річка попри дорогу плила (С. Пушик), Здивована Ійнечі бачила, як він стрілою пролетів попри ії юрту (В. Гжицький).

Значення, яке передають в українській мові конструкції V + ПОВ3 + Nacc V + ПРО3 + Nacc, V + ПОПРО3 + Nacc, V + ПОПРИ + Nacc, у російській мові репрезентоване структурою $\mathrm{V}+\mathrm{MИMO} \mathrm{+} \mathrm{Ngen,} \mathrm{яка} \mathrm{характеризує} \mathrm{рух} \mathrm{щодо} \mathrm{точки} \mathrm{простору,} \mathrm{про-}$ те позбавлена відтінку динамічної близькості до предмета-орієнтира. Зауважимо, що нині спостережено тенденцію до розширення вживання прийменників ПОВЗ і ПОПРИ в публіцистичному стилі.

Конструкція V + МІЖ (МЕЖИ) + Nасс функціонує зі значенням указівки на дію, спрямовану в межі простору, лімітованого кількома точками. Реалізується ця семантика за допомогою дієслів руху й спрямованої дії (iти, бігти, летіти, метнутися, закрастися, встромити, ловити, падати, кидати, вдарити, класти). Роль залежного компонента може виконувати будь-який іменник, що називає конкретний предмет чи об'єкт навколишньої дійсності. Детермінований член виражається однією або кількома лексемами, які позначають однорідну множинність (прути, кавуни, дерева, трава, гори, люди, молодь, худоба, коні), частини цілого (пальці, зуби, нігті), різні конкретні предмети (книга і зошит, шаба і стіна, молот і ковадло, сокира і пилка), парні предмети (брови, очі, коліна, береги): Сміх зблизив їх, $i$ вони пішли між молодь (О. Десняк), Здавалось, вербовий пень витяг з землі своє коріння та причвалав між люди (М. Коцюбинський), ...побрів y польскі Карпати, між панську худобу (В. Бабляк), Вони, як вівці 
3 кошари, збились до того тину ц̆, встромивши голови між залізні прути тину, жадно глитали ті звуки (В. Винниченко), Вона виймала в нього з-під боку рушницю і кидала ї̈ між кавуни (В. Яворівський), Потому засвітив свічку і застромив між пальиі (М. Коцюбинський), Поставів нас Господь на порозі з Азії в Європу, поклав як залізо між молот і ковало, - кують (Б. Лепкий), Янгол плаче, затиснувши руки між коліна (І. Багряний), А ще сих слів не сказав, як злодій вдарив його кулаком межи очі (В. Стефаник).

Для реалізації аналізованої семантики, крім сполук із прийменником МІЖ (МЕЖИ), використовуються структури з прийменником ПОМІЖ (ПОМЕЖИ). Зберігаючи синтагматичні можливості перших, вони вирізняються додатковим відтінком поширеності дії в просторі: ... ходив очима поміж зорі (В. Яворівський), Бігають поміж якісь засіки з колючого дроту, але скрізь натикаються на полічейських (О. Гаврилюк), О тій самій порі закрадався Сава, мов злодій, крізь городи й поміж хати до Рахіри (О. Кобилянська), На полотні, пробиваючисв поміж чорні скелі, як живий, бив водопад (В. Гжицький), А як соние родилося в крові і иілувало поміж довгі вії іх очі, то в єго сериі породилася пісня (В. Стефаник).

У сучасній російській мові не функціонують конструкції для реалізації розглядуваного значення. Локативна семантика, репрезентована синтаксичними структурами V + МІЖ (МЕЖИ) + Nacc в українській мові, може бути передана приблизно конструкціями $\mathrm{V}+\mathrm{K}+\mathrm{Ndat}, \mathrm{V}+$ МЕЖДУ + Ngen, V + МЕЖДУ + Ninst. Пор.: Надя враз метнулася між дерева $і$ невдовзі принесла волоських горіхів (О. Десняк) - Птииа метнулась к деревьям (Б. Можаєв) - Миа осторожно метнулась между деревъев... (Інтернет-ресурс) - ...тень метнулась между деревьями (Р. Самбук). Дослідники відзначають, що синтаксема V+MEЖ+Nacc хоч і мала низьку частоту вживання, проте існувала в російській мові (Павлова, 1977: 150) й була втрачена зовсім недавно. Про здатність прийменника МЕЖ сполучатися з акузативною словоформою знаходимо відомості в «Российской грамматике» М. В. Ломоносова (Ломоносов, 1952: 572). У «Толковом словаре живого великорусского языка» В. І. Даля зауважено, що прийменник «Между, межъ ... означает ... съ вин. окончательное направленье и движенье» (Ломоносов, 1952: 313). Граматики й лексикографічні джерела подальшої історії розвитку російської мови сполучення прийменника МЕЖ з іменниками в знахідному відмінку не фіксують. 
Конструкція V + ПЕРЕД + Nасс полісемантична. Вона 1) називає рух або іншу дію, спрямовану до переднього боку предмета (особи), 2) указує на дію, що відбувається попереду якогось предмета (особи). Перше значення реалізується за участю дієслів руху (прибігти, під'їхати, котитися, викотитися, упасти), спрямованої дії (сісти, поставити, совати, дивитися, подивитися). У ролі регулярних заповнювачів синтаксичної позиції, яку ці лексеми програмують, регулярно фіксуються іменники - найменування особи або об'ємного предмета, що має передній/задній бік (хлопець, дядько, сходи, хата, ворота, sанок, ноги). Функцію поширювача часто виконує іменник очі, що постає як метонімічна особа, а також особові та зворотний займенники (я, ти, він, себе): Перед сходи під'їала гетьманська парадна карета (Б. Лепкий), Ой прибіг мій козаченько та й перед вороma (Укр. нар. пісня), І вона совала йому перед очі сухі і чорні, немов залізні, руки (М. Коцюбинський).

Діпазон детермінувальних лексем, що беруть участь у формуванні другого з виділених значень, розширюється. Крім дієслів руху й спрямованої дії, його представляють лексеми зі значенням руху (ходити, бігати), конкретної фізичної дії (держати, тримати), оптичного сприйняття (дивитися). Семантичний спектр детермінованих членів залишається таким самим: I все перед мене задумані гори збігають (В. Сосюра), Широко витріщеними й невидющими очима він дивився просто перед себе й мотав головою (І. Багряний), Зав'язувала палецьь $i$, держачи його передсебе, біглаз столової на кухню (М. Коцюбинський).

3 тим же складом головних та залежних компонентів і з тими самими значеннями вживається також конструкція V + ПОПЕРЕД + Naсc. Від проаналізованої вище синтаксичної структури ії відрізняє більш або менш відчутний відтінок поширеності дії в просторі. Його привносить початковий елемент ПО- прийменника ПОПЕРЕД: Ставила страву поперед Устю (М. Коцюбинський), Того й вона весь час поперед нього ходить (В. Яворівський), Чом ти ходиш поперед мій двір (Укр. нар. пісня), Тоді відчула, як та мелодія погнала й погнала поперед себе все швидше й швидше (В. Яворівський), А Дмитро Золотий ходив поперед ворота з куснем грубої розвори (В. Стефаник).

У синтаксичній системі сучасної російської мови конструкцій $\mathrm{V}+$ ПЕРЕД + Nacc, V + ПОПЕРЕД + Nасс не виявлено. Щоправда, синтаксична сполука ПЕРЕД + Naсc була вживаною в мові XVIII сторіччя, 
зрідка фіксувалася в мові ХІХ століття (Станишева, 1966: 118) й сприймалася вже на той час як архаїчна (Сухотин, 1953: 239). Отже, синтаксема V + ПЕРЕД + Nасс вийшла з ужитку. На сучасному етапі розвитку російської мови значення, реалізоване нею, може бути репрезентоване за допомогою конструкцій V + K + Ndat i V + ПЕРЕД + Ninst. Пор.: ... молоток ... упав Олені перед ноги (О. Кобилянська) - Слепая ласточка бросается к ногам (О. Мандельштам); ... [він] бачив отут перед себе оцю трагічну сиену (І. Микитенко) - ... [он] долго глядит ... перед собой (П. Проскурін). Наведені приклади показують, що сполука $\mathrm{K}+\mathrm{Ndat}$ називає предмет, до якого спрямовано дію чи рух, й не ідентифікується з переднім/заднім боком предмета чи особи, тоді як ця семантична риса $є$ релевантною для конструкції $\mathrm{V}+$ ПЕРЕД + Nacc. Сполука ПЕРЕД + Ninst лише вказує на особу або предмет, попереду яких хто-, що-небудь розташовується. Аналізована семантика передається точніше, ніж у сполученні з прийменником К. На наш погляд, конструкція зі словоформою Ninst містить указівку на більший ступінь конкретності в проекції на місце предметів у просторі. У сполученні з Nасс ця конкретність розмивається.

Конструкція V + НАД + Nасс експлікує два значення: 1) називає дію, спрямовану вище від просторової одиниці; 2) указує на дію, спрямовану в бік якого-небудь місця. У реалізації обох значень беруть участь однакові групи дієслівних лексем і різні за семантикою групи іменників. Лексико-семантичний склад детермінувальних компонентів представлений безпрефіксними й префіксальними дієсловами динаміки, що позначають спрямовану дію або рух (віяти, податися, підбитися, посилати, іти, піти, плисти). Перше значення виражається за допомогою іменників - назв більш або менш чітко лімітованих просторів, а також окремих конкретних територій і предметів (гори, степ, луки, ліс, бір, місто, село, застава, квартал, хата, стіл, кущ): Над ліси підносилися рицарські списи (М. Бажан), Бур'яни аж над хату повиганялись (В. Яворівський). Реалізатором другого значення $є$ іменники - номінування акваторій (ріка, море, потік, Прут, вода): Пішла я аж над ріку (С. Пушик), Огледившись довкола ще раз, знов подався над потік (В. Гжицький), І плювала, і йшла до воріт або над став шукати жінок, ласих на розмову (В. Стефаник), Цікавіші подались навіть горою над Прут, звідки можна було бачити все (М. Коцюбинський). Описуване значення в українській мові може також 
репрезентувати конструкція V + ПОНАД + Nасс: Тільки Мариночка стояла як заворожена, а зір ї̈ летів кудись понад хати, понад поля, далеко-далеко (Р. Купчинський), Гашіца висовує голову понад кущі (М. Коцюбинський), ...мама у жнива ходили понад ріку та й йойкали (С. Пушик), ... иитринове сонце плило понад сусідні квартали (О. Кундзіч), Ой летіла зозуленька понад море в гай та впустила сиве пірие у тихий Дунай (Укр. нар. пісня), Так сьогодні гарно піч горіла, либонь, вітер понад гори пішов (В. Яворівський). Від розгляданої вище вона відрізняється «додатковим відтінком поширення в просторі» (Вихованець, 1971: 108), який формує первинний прийменник ПО-, що входить до структури прийменника ПОНАД. Крім виділених значень, за синтаксичною структурою із залежною позицією ПОНАД + Nасс закріплюється семантика «розташування кого-, чого-небудь у безпосередній близькості від точки-маркера». Синтагматичні можливості прийменника ПОНАД розширюються: до складу конструкцій поряд із дієсловами динаміки входять вербативи статики (бути, стояти): Стоять верби понад воду (Укр. нар. пісня). Конкретні факти дають право не погодитися з думкою I. Р. Вихованця про те, що конструктивним центром моделі V + ПОНАД + Nacc $€$ тільки ті дієслова, які «означають рух, переміщення в просторі» (Вихованець, 1971: 108). Досліджувана синтаксична структура, як i V + НАД + Nacc, має відтінок розмовності, уживається здебільшого у творах художньої літератури та фольклорі.

У системі синтаксичних засобів російської мови, які виражають просторові відтінки, конструкції V + НАД + Naсc не зафіксовано. Значення, репрезентовані нею в українській мові, у російській мові актуалізуються по-різному. Так, семантику «назва дії, спрямованої вище від просторової одиниці» реалізує синтаксема V + НАД + Ninst, пор.: Пливуть над села і над луки пісенноносні кораблі (М. Бажан) - Над сонным лугом коршун кружит (О. Блок), ... пльли над хутором порою белье, тронутые изморозной белизною облака (М. Шолохов). План змісту «вказівка на дію, спрямовану в бік якого-небудь предмета» реалізує структура $\mathrm{V}+\mathrm{K}+\mathrm{Ndat}$, пор.: Піде над річку, порюмсає - i знов добре (У. Самчук) - И с берега огромная овчарка величественно двигалась к реке (М. Заболоцький). Російські сполуки із залежними позиціями НАД + Ninst i K + Ndat не є тотожними щодо семантики українським конструкціям із детермінованим 
компонентом НАД + Nacc. Синтаксична структура V + НАД + Ninst указує на місцерозташування предмета або вияв тієї чи тієї дії стосовно якої-небудь точки простору, але не визначає його спрямованості вище від просторового орієнтира, що властиве синтаксемі української мови V + НАД + Nacc. Конструкція V + K + Ndat сигналізує про наближення кого-, чого-небудь до кого-, чого-небудь, указує на загальну спрямованість реалізації дії чи руху, проте позбавлена семантичного відтінку «близькість між динамічним предметом і точкою, у напрямку якої здійснюється дія або рух». Цей відтінок певною мірою експлікується в конструкціях української мови з поширювачем НАД + Nacc.

\section{Висновки}

Отже, способи репрезентації знахідного відмінка локативної семантики за багатьма параметрами збігаються в українській та російській мовах. Це стосується передусім конструкцій із прийменниками НА, В/У (рос. У), ЧЕРЕЗ, КРІЗЬ (рос. СКВОЗЬ), ЗА, ПІД (рос. ПОД). Їхня загальна семантика полягає у вказівці на рух або іншу спрямовану дію. Реалізація цього значення пов'язана з дієсловами динаміки, переміщення, фізичної дії, що асоціюється з рухом. Асиметрію простежено на рівні конструкцій із прийменниками ПОВЗ, МІЖ (МЕЖИ), ПОМІЖ (ПОМЕЖИ), ПЕРЕД, ПОПЕРЕД, НАД, ПОНАД. За кожною з них закріпився конкретний тип семантики, жорстко регламентований лексико-семантичний набір детермінувальних і детермінованих компонентів, функціональний потенціал. Зміст, який репрезентують українські локативні синтаксеми, у російській мові має інше представлення. Воно лише почасти корелює з тим або тим конкретним українським типом просторового значення.

Порівняльний аналіз реалізації інших значень знахідного відмінка в українській і російській мовах вважаємо перспективним для виявлення симетричних і асиметричних явищ у граматичній структурі цих східнослов'янських мов.

\section{ЛІТЕРАТУРА}

1. Вихованець I. Р. Синтаксис знахідного відмінка в сучасній українській літературній мові. Київ: Наук. думка, 1971. 120 с. 2. Вихованець I. Р. Система відмінків української мови. Київ: Наук. думка, 1987. 231 с. 3. Даль В. И. Толковый словарь живого великорусского языка: в 4 т. Москва: Русск. язык, 1978. Т. 2.779 с. 4. Іваненко 3. I. Система прийменникових конструкцій адвербіального значення. 
Київ; Одеса: Вища шк., 1981. 143 с. 5. Ломоносов М. В. Полное собрание сочинений. Москва; Ленинград, 1952. T.VII. 995 с. 6. Павлова Р. Пространственные конструкции в древнерусском языке в сопоставлении с древнеболгарским языком. София: БАН, 1977. 239 с. 7. Станишева Д. С. Винительный падеж в восточнославянских языках. София: БАН, 1966. 295 с. 8. Сухотин В. П. Глагольные словосочетания с винительным падежом в прозе М. Ю. Лермонтова. Материалы и исследования по истории русского литературного языка. Москва, 1953. Т. 3. С. 200-240. 9. Тимченко Є. К. Акузатив в українській мові. Київ: Вид-во ВУАН, 1928. 101 с.

\section{REFERENCES}

1. Vykhovanets, I. R. (1971). Syntaksys znakhidnoho vidminka v suchasnii ukrainskii literaturnii movi [The Syntax of Accusative in Contemporary Ukrainian Literary Language]. Kyiv : Nauk. dumka [in Ukrainian]. 2. Vykhovanets, I. R. (1987). Systema vidminkiv ukrainskoi movy [The system of cases of the Ukrainian language]. Kyiv: Nauk. dumka [in Ukrainian]. 3. Dal, V. I. (1978). Tolkovyiy slovar zhivogo velikorusskogo yazyika [An intelligent dictionary of the living Great Russian languag]. (Vol. 2). Moskva: Russk. Yazyik [in Russian]. 4. Ivanenko, Z. I. (1981). Systema pryimennykovykh konstruktsii adverbialnoho znachennia [System of prepositional constructions of adverbial value]. Kyiv; Odesa: Vyshcha shk. [in Ukrainian]. 5. Lomonosov, M. V. (1952). Polnoe sobranie sochineniy [Complete collection of works]. V. VII. Moskva; Leningrad [in Russian]. 6. Pavlova, R. (1977). Prostranstvennyie konstruktsii $v$ drevnerusskom yazyike $v$ sopostavlenii s drevnebolgarskim yazyikom [Spatial Constructions in Ancient Russian in Comparison with Ancient Bulgarian]. Sofiya: BAN [in Russian]. 7. Stanisheva, D. S. (1966). Vinitelnyiy padezh v vostochnoslavyanskih yazyikah [The accusative case in East Slavic languages]. Sofiya: BAN [in Russian]. 8. Suhotin, V. P. (1953). Glagolnyie slovosochetaniya s vinitelnyim padezhom v proze M. Yu. Lermontova [Verb phrases with accusative case in prose of M. Yu. Lermontov ]. Materialyi $i$ issledovaniya po istorii russkogo literaturnogo yazyika - Materials and research on the history of Russian literary language. (Vol. 3), (pp. 200-240). Moskva [in Russian]. 9. Tymchenko, Ye. K. (1928). Akuzatyv v ukrainskii movi [Accusative in Ukrainian]. Kyiv: Vyd-vo VUAN [in Ukrainian].

Степаненко Ніна Степанівна - кандидат філологічних наук, доцент, завідувач кафедри філологічних дисциплін і методик їх викладання, Полтавський національний педагогічний університет імені В. Г. Короленка; вул. Остроградського, 2, м. Полтава, 36000, Україна.

E-mail: filolkafedra@ukr.net

https://orcid.org/0000-0002-0934-784X

Stepanenko Nina - PhD in Philology, Associate Professor, Head of the Department of Philological Disciplines and Teaching Methods, V. H. Korolenko Poltava National Pedagogical University; Ostrohradskoho Str. 2, Poltava, 36000, Ukraine. 